Vol. 3, No. 1, 2016

UDC 338.24:658.152:621

Z. O. Koval

$\mathrm{PhD}$, Associate Professor,

Lviv Polytechnic National University

\title{
EVALUATION INDICATORS OF THE MARKETING STRATEGIES EFFICIENCY OF VALUE-BASED ENTERPRISES
}

\begin{abstract}
The article presents indicators used for evaluating the enterprise marketing strategy efficiency with current approaches. Trends in evaluating marketing strategy of value-based enterprises are analyzed and specified. There are selected and grounded evaluation indicators of marketing strategies efficiency of value-based enterprises. The system of indicators corresponding to the selected principles and demands of value-based management as well as to the suggested efficiency evaluation criteria is developed. The aim of this research is to analyze advantages and disadvantages of current evaluation indicators of marketing strategies efficiency in the process of their application as well as develop new indicators to meet the requirements of value-based enterprises. As a result of the research a system of indicators to carry out an objective and overall evaluation of the marketing strategy according to the integral efficiency indicator and in compliance with the requirements of value-based enterprise management is proposed. The research results can be applied in the evaluation model of the marketing strategy options at the value-based enterprises with the aim of choosing the best option.
\end{abstract}

Key words: indicators of efficiency evaluation, marketing strategy, marketing strategy efficiency, strategy options, system of indicators, value-based enterprise.

\section{Problem statement}

Planning enterprise activities involves forming strategies of its development, the general strategy, in particularly, which determines the enterprise business line, its strategic goal, the tasks to be performed to achieve it as well as its functional strategies. Marketing strategy is a detailed elaboration of the enterprise development directions in the field of marketing. Efficient marketing strategy enables an enterprise to offer its customers products that maximally meet the demand, are sold at favorable prices, at their earliest convenience, and in the convenient place, thus guaranteeing the possibility for the enterprises to compete in the market efficiently.

In case of value-based management, extremely important is availability of the relevant indicators that make it possible to evaluate not only the efficiency of the enterprise marketing strategy but also its impact on the enterprise value. However, when making a selection of indicators for such efficiency evaluation, it is essential to answer three major questions: for what purposes these indicators will be used; what benefit the results of their analysis will bring; and who needs them.

\section{A review of recent research and publications}

The analysis of recent research and publications in which the solution to the given problem is presented, shows the variety of approaches to the enterprise marketing strategy formation. The related research works reveal a number of trends in evaluating the marketing strategy efficiency, one of the trends being its evaluation by means of summing up the results of production and sales activities improvement with the account of the maximum use of market opportunities, the increase in the forecasts reliability, identification of the market segment for certain products etc. Other trends concern evaluation of marketing strategies efficiency according to such factors as the number of customers, marketing integration, adequacy of information etc., though there is no algorithm for their calculation. Several trends are based on the assumption that marketing performance consists in sales growth and increase in profits. However, these are final results, and they are influenced not only by marketing but also by other enterprise performance factors, such as personnel qualification and financial potential. Consequently, such assessment is too simplified and not very objective. It has also been proposed to evaluate marketing strategy efficiency as a total of expenses on marketing, though in this case it is evaluated marketing cost-effectiveness rather than marketing strategy efficiency.

In the majority of international publications [3-5, 8, 11-15] marketing expenses are being treated as an investment into enterprise efficiency. The research into the barriers hindering the 


\section{Z. O. Koval}

objective evaluation of marketing performance efficiently conducted by the auditing and consulting firm "Deloitte" is an important contribution to the issue of evaluating marketing performance efficiency. One of the major latest research is a global evaluation system of marketing investments called the "optimal marketing" [13] based on analyzing the data on customers' performance evaluation obtained through CRM (Customer Relationship Management) system. The research conducted by J. Lenskold [14], who not only interprets expenses on marketing as investment but also suggests evaluating efficiency using ROI (Return on Investment) metric, is notable in this field. M. McDonald and P. Mouncey consider investments into marketing taking into account their ROI time [15]. As far as Ukrainian researchers are concerned, they still, for various objective and subjective reasons, look at investments into marketing as expenses. One of the principal reasons for this is the necessity to take time factor into account. Some time is needed to feel the effects of applying a certain marketing strategy. The absence of a common viewpoint on determining basic indicators for evaluating the efficiency of marketing strategies as well as the absence of an evaluation technique, in particular, for value-based enterprises, makes these issues particularly topical.

\section{Objectives of the article}

The article aims at justifying the expediency of selecting adequate indicators of marketing strategy efficiency of value-based enterprises. The following tasks are set:

- to analyze the approaches being used for evaluating the efficiency of enterprise marketing strategy;

- to study the trends of marketing strategy evaluation and to adapt them for being used by value-based enterprises;

- to justify the expediency of selecting indicators of marketing strategy efficiency for value-based enterprises.

\section{Results and discussion}

Given the fact that any activity leads to some results manifested in its outcomes that may be evaluated, the results of selecting and applying the marketing strategy are visible in the achievement of economic, managerial, social, communicative, competitive and other effects. Such diversity of results as well as increase in the role of marketing strategies in the enterprise activities have given rise to a considerable number of trends in evaluating the enterprise marketing strategy efficiency.

Generally speaking, efficiency may be defined as the correlation between the outcomes of any activity (or measure) and the expenses on their high-quality achievement. Thus, efficiency characterizes processes and activities of managerial nature, reflecting the level of achieving the goal, and may imply: a clearly stated specific outcome; correspondence of the achieved result to the most possible, ideal or planned outcome; costs and benefits correlation; quantitative characteristics of enterprise performance; the level of achieving the goal.

Evaluation of efficiency of the enterprise marketing strategies involves selection of the following evaluation criteria: effectiveness, expediency, costs, ethicality, rationality, adaptability, reliability, dynamics. Such criteria will enable comprehensive efficiency evaluation of marketing strategies. In particular, effectiveness describes the expected, planned or actually achieved result of marketing strategy implementation by an enterprise. Expediency criterion marks correspondence of marketing strategy and effects of its implementation to the goal set by the enterprise. Costs criterion characterizes the level of expected or obtained business expenditures as a result of the selected strategy implementation. Ethicality criterion characterizes correspondence of the selected strategy to ethical, social and ecological standards. Rationality characterizes correspondence of the marketing strategy to the core principles of enterprise development and its marketing activities. Adaptability criterion marks the level of marketing strategy adjustment to the conditions of external and internal environment, its flexibility depending on the impact of these conditions. Reliability characterizes the ability of the marketing strategy to preserve with time the value of all parameters within certain limits, indicating that it can be applied in specified environments and conditions. Dynamics characterizes timeframe of marketing strategy implementation as well as possibility of its development.

Application of the aforementioned criteria for the evaluation of the enterprise marketing strategy will make it possible to analyze not only the efficiency of a certain strategy but also to compare variants of strategies in order to select the best one. In particular, one may use the model of advantages of the enterprise marketing strategies (Fig. 1), that has been created by analogy with the polygon of competitiveness, and reflects correlation of various indicators on the plane. To display the level of significance of each criterion under 
study, a certain scale of measurement is used, for example level evaluation. Thus, by means of polygons of advantages for the enterprise strategies depicted on one plane, it is possible to analyze their efficiency level according to various criteria.

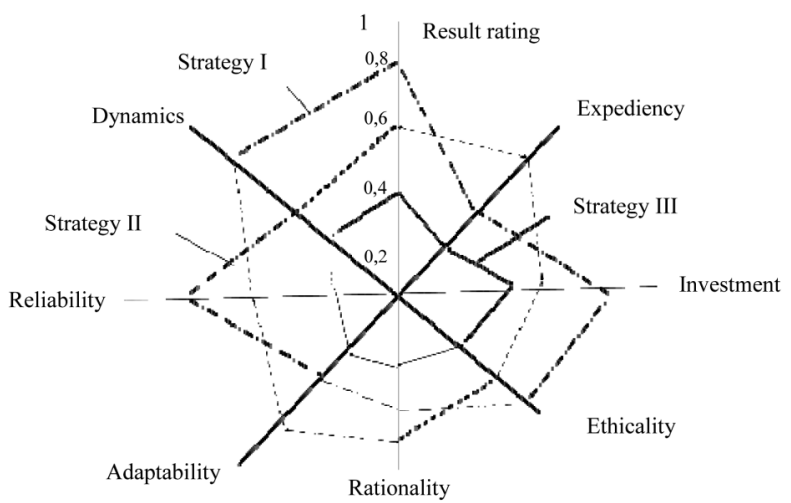

Fig. 1. The model of comparison of the enterprise marketing strategy variants (criteria values are determined according to the level scale from 0 to 1 )

The application of the suggested marketing strategy evaluation technique on the basis of the suggested criteria will make it possible to visualize and evaluate advantages and disadvantages of each strategy being evaluated, and, as a result, select the most efficient one.

Quantitative estimation of a marketing strategy may be obtained applying economic and mathematical methods. In particular, the marketing strategy efficiency in general terms may be presented through these three basic indicators: the period of time for strategy implementation $(T)$, costs of strategy implementation and possibilities of cost reduction $(C)$, expected or obtained result (effect) from the application of the strategy $(R)$.

Having defined the enterprise marketing strategy efficiency as $E$, we can present this indicator as a function of three variables $(T, C$, and $R)$ :

$$
E=f(T, C, R) \rightarrow \max .
$$

Therefore, we obtain the evaluation model of enterprise marketing strategy efficiency according to certain variants. Let function $P(x)$ denote expected (or achieved) outcome of strategy application, where the variable $x$ characterizes the number of strategy variants. Then, efficiency of their implementation may be presented by $E(x)$ function, which is the derivative of the amount of $P(x)$, that is, $E(x)=d P(x) / d x$. Thus, the speed of achieving the intended effect $P(x)$ as well as the rate of strategy efficiency change may be determined by the following equations:

$$
\begin{gathered}
R(x)=\frac{d E(x)}{d x}=\frac{d^{2} P(x)}{d x^{2}}, \\
Z(x)=\frac{\frac{d E(x)}{d x}}{E(x)}=\frac{d[\ln (E(x))]}{d x} .
\end{gathered}
$$

The proposed technique will make it possible to evaluate the efficiency of the enterprise marketing strategies in terms of the speed of achieving the intended effect and the rate of the strategy efficiency change.

Therefore, we suggest grouping indicators that should be used at various stages of marketing strategy life cycle (Table 1).

\section{Peculiarities of applying marketing strategy efficiency evaluation indicators of at various stages of its life cycle}

\begin{tabular}{|c|l|l|}
\hline Stages & \multicolumn{1}{|c|}{ The essence of the stage } & \multicolumn{1}{|c|}{ Evaluation indicators of marketing strategy efficiency } \\
\hline Development & $\begin{array}{l}\text { Determination of goals and missions, tasks and } \\
\text { objectives of the activity; } \\
\text { Analysis of strengths and weaknesses, } \\
\text { opportunities and threats; } \\
\text { Determination and development of alternative } \\
\text { courses of action and directions. }\end{array}$ & $\begin{array}{l}\text { Evaluation of various strategy alternatives in terms of: } \\
- \text { feasibility; } \\
- \text { validity; } \\
- \text { competitiveness. }\end{array}$ \\
\hline Selection & $\begin{array}{l}\text { Analysis of developed strategies; } \\
\text { Comparison of alternative strategies; } \\
\text { Selection of optimal strategy. }\end{array}$ & $\begin{array}{l}\text { Comparison of alternative strategies by the following } \\
\text { indicators: effectiveness, expediency, costs, ethicality, } \\
\text { rationality, adaptability, reliability, and dynamics. }\end{array}$ \\
\hline Implementation & $\begin{array}{l}\text { Determination and substantiation of marketing } \\
\text { behavior; } \\
\text { Arrangement of conditions for efficient strategy } \\
\text { application; } \\
\text { Coordination of various directions for strategy } \\
\text { implementation. }\end{array}$ & $\begin{array}{l}\text { Evaluation of opportunities and threats for a strategy } \\
\text { implementation according to the following indicators: } \\
\text { - creative approach, } \\
\text { - tactics of marketing activity implementation, } \\
\text { - marketing management. }\end{array}$ \\
\hline Evaluation & $\begin{array}{l}\text { Analysis of the strategy implementation results; } \\
\text { Analysis of time and resources expenditures; } \\
\text { Analysis of the level of the goal achievement. }\end{array}$ & $\begin{array}{l}\text { Strategy efficiency evaluation by changes in effectiven- } \\
\text { ess, costs, ethicality, rationality, adaptability, reliability, } \\
\text { dynamics, and expediency. }\end{array}$ \\
\hline
\end{tabular}


As a marketing strategy efficiency characterizes the efficiency of its development and implementation processes, its evaluation should include analysis of the following:

- validity and feasibility of plans;

- general purpose and objectives of marketing strategy;

- correctness of choosing the strategy type;

- strategy components (concept, measures and actions, indicators and criteria etc.);

- degree of achieving the goal, results, expenditures, competitiveness and flexibility of the strategy etc.

The purpose of the marketing strategy efficiency analysis consists in obtaining an objective evaluation of the effect received from implementation of certain marketing activities, and its comparison with expenditures and the goal set. However, in the context of value-based management this purpose is accompanied with assessment of the enterprise value change due to implementing these marketing activities.

Consequently, value orientation of management makes certain adjustments in the marketing strategy efficiency evaluation. Taking this into consideration, the analysis of marketing strategy efficiency will also include assessment of the enterprise value increase and the contribution of marketing activities into it; analysis of the marketing activities efficiency and the costs of marketing measures taken; profitability analysis of investments into marketing activities; assessment of the effects obtained and the influence of factors on the efficiency of marketing strategies as well as the reserves for its increase.

The essence of efficiency evaluation of marketing strategies at value-based enterprises lies in analyzing the strategy development and the results of its implementation, their correlation with the goals set and the costs incurred. The analysis of validity and feasibility of plans involves the comparison of strategic indicators of the enterprise performance with the indicators of the current and/or previous periods. A considerable difference in these indicators should be substantiated either by additional attraction of resources (financial, human, material etc.) into the enterprise activities or their withdrawal.

The analysis of the integrated index formation will make it possible to reveal the reserves, i.e. unused opportunities for the enterprise marketing strategy efficiency enhancement that should be considered while developing the enterprise marketing strategy in future.

\section{research \\ Conclusions and prospects for future}

The choice of indicators for evaluating the marketing strategies efficiency of value-based enterprises should imply getting an objective evaluation of the effect these strategies have on increasing the value of the enterprise assets. As there is the need in creating the appropriate image of the enterprise and increasing the enterprise value, such evaluation is of key importance in making an assessment of the general effect of marketing strategies implementation in case of value-based management. Application of the suggested indicators for the evaluation of the enterprise marketing strategies will make it possible to obtain objective assessment of their efficiency, being the background for their further considerable competitive advantages. The selection of principles and directions of evaluation may be substantiated by the significance of marketing strategies in the enterprise value formation. The further research will involve the development of methodological basis of assessment of marketing strategies efficiency at value-based enterprises.

\section{References}

1. Upravlinnia innovatsiinymy protsesamy $v$ mezhakh ekosystemy: Monohrafiia / N. I. Chukhrai, R. Patora, A. H. Zahorodnii, H. M. Zakharchyn ta in., za nauk. redaktsiieiu N. I. Chukhrai. - Lviv: Vydavnytstvo Lvivskoi politekhniky, 2012. - 216 s.

2. Tsyhankova T. M. Suchasni modeli ta tendentsii rozvytku stratehichnoho marketynhu /T. M. Tsyhankova // Marketynh v Ukraini. - 2004. - No. 2(24). S. 31-36.

3. Porter M. Konkurentnaia stratehyia: Metodyka analyza otraslei y konkurentov / M. Porter, per. s anhl. Y. Mynervyna. - M.: Alpyna Pablysher, 2011. - $454 \mathrm{~s}$.

4. Tompson A. Stratehycheskyi menedzhment. Kontseptsyy y sytuatsyy dlia analyza / A. Tompson, A. Stryklend, per. s anhl., 12-e yzd. - M.: Yzd. dom "Vyliams", 2006. - $928 s$.

5. Krevens D. Stratehycheskyi marketynh / D. Krevens, per. s anhl. - M.: Yzd. dom "Vyliams", 2008. - 512 s.

6. Marketynhovi stratehii rozvytku ta konkurentospromozhnosti sotsialno-ekonomichnykh system $v$ umovakh hlobalizatsii : monohrafiia / [I. V. Taranenko, O. V. Dashevska, D. Iu. Liashko ta in.]. Dnipropetrovsk: DUEP, 2010. - 304 s.

7. Balabanyts A. V. Obgruntuvannia mekhanizmu vymiriuvannia rezultatyvnosti marketynhovoi vzaiemodii pidpryiemstva iz tsilovym rynkom / A. V. Balabanyts [Elektronnyi resurs] // Torhivlia $i$ rynok Ukrainy. - 2009. - No. 28. - Vol. 3. - S. 8. - 


\section{Evaluation Indicators of the Marketing Strategies Efficiency of Value-Based Enterprises}

Rezhym dostupu do zhurn.: http: // www. nbuv.gov. ua/portal/Soc_Gum/Tiru/2009_28_3/index.htm.

8. Marketynhovi pokaznyky: Bilshe 50 pokaznykiv, yaki vazhlyvo znaty kozhnomu kerivnyku / [U. Pol Ferris, T. Neil Bendl, I. Filipp Pfaifer, Devid Dzh. Reibshtein]; per. z anhl.; za zah. red. I. V. Taranenko. - Dnipropetrovsk: Balans Biznes Buks, 2009. - 480 s.

9. Marketynhovi stratehii rozvytku ta konkurentospromozhnosti sotsialno-ekonomichnykh system $v$ umovakh hlobalizatsii : monohrafiia / [I. V. Taranenko, O. V. Dashevska, D. Iu. Liashko ta in.]. Dnipropetrovsk : DUEP, 2010. - 304 s.

10. Marketynhovi pokaznyky: Bilshe 50 pokaznykiv, yaki vazhlyvo znaty kozhnomu kerivnyku / [U. Pol
Ferris, T. Neil Bendl, I. Filipp Pfaifer, Devid Dzh. Reibshtein] ; per. z anhl.; za zah. red. I. V. Taranenko. - Dnipropetrovsk : Balans Biznes Buks, 2009. - $480 \mathrm{~s}$.

11. Marketing in 3D // Deloitte report, London, 2007.

12. Kumar V. Customer Relationship Management : Concept, Strategy and Tools / V. Kumar, W. Reinartz. John Wiley \& Sons, Inc., 2nd ed., 2012. - 379 p.

13. Lenskold J. D. Marketing ROI : the path to campaign, customer, and corporate profitability /J. D. Lenskold. New York: McGraw-Hill, 2003. - 271 p.

14. McDonald M. Marketing accountability : how to measure marketing effectiveness / M. McDonald, P. Mouncey. - London and Philadelphia: Kogan Page, 2009. - 294 p. 
